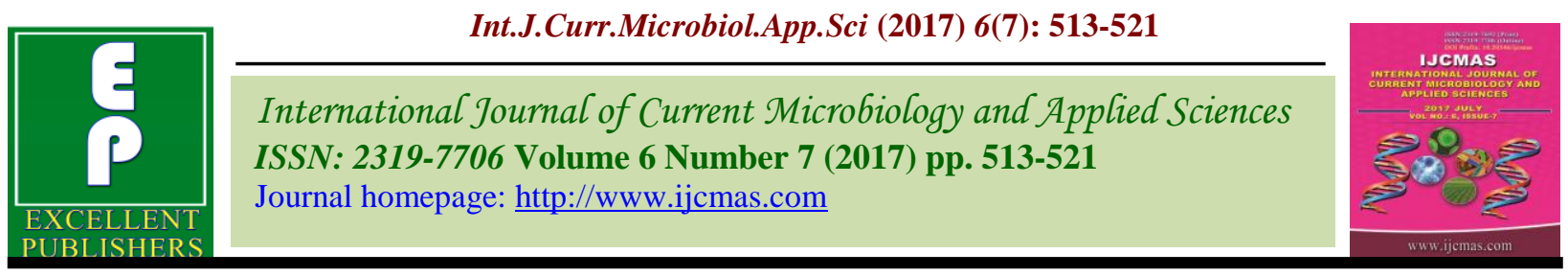

Original Research Article

https://doi.org/10.20546/ijcmas.2017.607.062

\title{
Productivity of Kharif Maize (Zea mays L.) as Influenced by Sub Soiling and Planting Methods
}

\author{
Gurbir Singh, J.S. Kang*" and Harmeet Singh \\ Department of Agronomy, Punjab Agricultural University, Ludhiana-141004, Punjab, India \\ *Corresponding author
}

\section{A B S T R A C T}

The present investigation, "Productivity of Kharif maize (Zea mays L) as influenced by sub soiling and planting methods" was carried out at Students' Research Farm, Department of Agronomy, Punjab Agricultural University, Ludhiana during Kharif 2016. The soil of

Keywords

Bulk density, Conventional tillage, Infiltration rate, Maize,

Minimum tillage, Penetration resistance, Sub soiling.

Article Info

Accepted: 04 June 2017 Available Online: 10 July 2017 the experimental field was sandy loam. The experiment comprised of fifteen treatments viz., minimum tillage flat planting (without sub soiling, sub soiling at $1 \mathrm{~m}$, sub soiling at $1 \times 1 \mathrm{~m}$, sub soiling at $1.5 \mathrm{~m}$, sub soiling at $1.5 \times 1.5 \mathrm{~m})$. Conventional tillage flat planting (without sub soiling, sub soiling at $1 \mathrm{~m}$, sub soiling at $1 \times 1 \mathrm{~m}$, sub soiling at $1.5 \mathrm{~m}$, sub soiling at $1.5 \times 1.5 \mathrm{~m}$ ). Conventional tillage ridge planting (without sub soiling, sub soiling at $1 \mathrm{~m}$, sub soiling at $1 \times 1 \mathrm{~m}$, sub soiling at $1.5 \mathrm{~m}$, sub soiling at $1.5 \times 1.5 \mathrm{~m}$ ). All the three planting methods (minimum tillage flat planting, conventional tillage flat planting, conventional tillage ridge planting) did not show any significant difference in relation to yield attributes like cob length, thousand grain weight and grain yield. Cob yield and grain yield was statistically at par in sub soiling treatments but significantly better than no sub soiling treatment. Bulk density was not influenced by any of the planting methods while sub soiling effect the bulk density of soil and results were significant at $15-30 \mathrm{~cm}$ and $30-45 \mathrm{~cm}$ depth. Infiltration rate $\left(\mathrm{cm} \mathrm{hr}^{-1}\right)$ was higher in minimum tillage treatment at various time intervals. Penetration resistance was lowest in the treatment where is sub soiling is done at $1 \mathrm{x} 1 \mathrm{~m}$ while highest resistance was noticed where no sub soiling is done. As all the planting methods results were at par in relation to productivity of crop the minimum tillage flat planting is better as residues were retained and less mechanical interference is involved. Similarly sub soiling done at various distances show similar results but better than no sub soiling. So, sub soiling at $1.5 \mathrm{~m}$ distance is good as less ploughing is involved.

\section{Introduction}

Maize (Zea mays L.) is the third most important crop ranks next to wheat and rice in the world and one of the important staple food crop. It has highest genetic yield potential among cereals and known as queen of cereals. Maize is considered as a most important option for diversifying agriculture in India. Maize provides nutrients for human and animals and also serves as a raw material for the production of food sweeteners, starch, alcoholic beverages, protein and oil (Ramesh et al., 2014). Maize being C4 crop, has potential for yield and can prove to be the best substitute crop for overcoming the hazards associated with paddy cultivation (Ram et al., 2010). It is understood to enjoy enormous potential which yet remained untapped. The strong demand is putting tremendous pressure 
on production, hence increasing the price of maize, which in turn has raised food prices in general.

A compaction in the soil layer, due to its high strength and less porosity, reduces the roots of the crop in upper layers and also the volume of soil that can be used by plants for water and the nutrients (Hammel 1994).Many sandy-loam soils have tillage pans because of practicing tillage again and again and compaction in no tillage soils, which must be deep tilled to increase the yield. Sub soiling breaks compaction of soil layers, increases water infiltration and water movement in the soil, helps in better root growth which increases production of the crop (Bennie and Botha 1986). Tillage practices and wheat residue management effect on the yield of the maize and properties of soil has been shown by several scientists (Unger, 1991; Raimboult and Vyn, 1991; Lal et al., 1994). Sub soiling helps in increased maize grain yield and the highest yield was obtained with tillage depth of $90 \mathrm{~cm}$ (Varsa et al., 1997). Frequent tillage land quality, increase soil erosion and soil hardness (Hamza and Anderson, 2005). Yield attributes and maize grain yield did not show significant difference in conventional and no tillage treatments (Ram et al., 2010).

Keeping these considerations in view, the present study entitled "Productivity of kharif maize (Zea mays L.) As influenced by sub soiling and planting methods" was planned with these objectives: 1) to study the effect of sub soiling on productivity of maize under different planting methods. 2) To determine the optimum spacing of sub soiling in maize and effect of interaction between sub soiling and planting methods.

\section{Materials and Methods}

A field experiment was conducted at Punjab Agricultural University, Ludhiana during
2016 in North-western India. The experimental site is situated at $30^{\circ}$ 54' $\mathrm{N}$ latitude and $75^{\circ} 48^{\prime} \mathrm{E}$ longitude at a height of $247 \mathrm{~m}$ above the mean sea level in the central plain region of Punjab under Trans-Gangetic agro-climatic zone of India and is characterized by sub-tropical and semi-arid type of climate with annual rainfall of 500$750 \mathrm{~mm}$. The study was aimed to evaluate the effect of sub soiling and planting methods on maize productivity as well as on properties of the soil.

The soil of the experimental field was sandy loam having normal $\mathrm{pH}$, medium organic carbon and available $\mathrm{N}$, sufficient available $\mathrm{K}$ and high available P. The experiment was conducted in strip plot design comprised of fifteen treatments viz., minimum tillage flat planting without sub soiling, minimum tillage flat planting with sub soiling at $1 \mathrm{~m}$, minimum tillage flat planting with sub soiling at $1 \times 1 \mathrm{~m}$, minimum tillage flat planting with sub soiling at $1.5 \mathrm{~m}$, minimum tillage flat planting with sub soiling at $1.5 \times 1.5 \mathrm{~m}$, conventional tillage flat planting without sub soiling, conventional tillage flat planting with sub soiling at $1 \mathrm{~m}$, conventional tillage flat planting with sub soiling at $1 \times 1 \mathrm{~m}$, conventional tillage flat planting with sub soiling at $1.5 \mathrm{~m}$, conventional tillage flat planting with sub soiling at $1.5 \times 1.5 \mathrm{~m}$, conventional tillage ridge planting without sub soiling, conventional tillage ridge planting with sub soiling at $1 \mathrm{~m}$, conventional tillage ridge planting with sub soiling at $1 \times 1 \mathrm{~m}$, conventional tillage ridge planting with sub soiling at $1.5 \mathrm{~m}$, conventional tillage ridge planting with sub soiling at $1.5 \times 1.5 \mathrm{~m}$. Sub soiling was done upto $30-35 \mathrm{~cm}$ depth before sowing of the cultivar PMH 1. In minimum tillage flat planting residues were retained in the field and only sub soiling is done. In conventional tillage flat planting after sub soiling the field is ploughed twice and the 
planking is done while in conventional tillage ridge sowing first sub soiling is done then field is ploughed twice and ridges were made. The crop was harvested on 26 September 2016. The data on bulk density was recorded by core sampler and infiltration rate was recorded by double ring infiltrometer method while the penetration resistance was checked with the help of digital cone penetrometer at two random locations within the plot. The data were analysed using CPCS1 software with $5 \%$ level of significance for comparing the treatment means.

\section{Results and Discussion}

\section{Effect on growth attributes}

The data on plant height recorded at 30, 60 days after sowing (DAS) and at harvest. Planting methods does not show any significant difference in relation to plant height. Plant height of minimum tillage flat planting was more at 60 DAS and at harvest but was statistically similar with the conventional tillage flat planting and conventional tillage ridge planting (Table 1).

Plant height was affected significantly by sub soiling at 60 DAS and at harvest. Plant height was higher in the treatments where sub soiling is done at different spacing and significantly better than the treatment where no sub soiling is done (Table 1). Better soil physical conditions lead to increase in plant height of the crop under sub soiling. LAI (leaf area index) increased with increase in crop age up to 60 DAS and thereafter it started declining due to senescence of lower leaves. LAI was not significantly different under any of the planting methods (Table 2). This may be due to the no effect on emergence count and plant height due to any of the planting methods. In case of sub soiling treatments the results were statistically at par where sub soiling is done but significantly better than no sub soiling treatment at 60 days after sowing and at harvest (Table 2).

Values of periodic dry matter accumulation increased progressively with the advancement of crop age and maximum values were recorded at harvest of crop. There was no significant difference recorded in dry matter accumulation after 30 days of sowing in all the planting methods as well as in sub soiling treatments. Minimum tillage flat planting has high dry matter accumulation at 60 DAS and at harvest but all the planting methods were statistically at par at all intervals (Table 3 ). In plots where sub soiling is done shows the significant difference than the plots where no sub soiling is done (Table 3).

\section{Effect on yield and yield attributes}

A perusal of data revealed that the cob length was not significantly differing under any of the planting method or the sub soiling treatment (Table 4). The data on cob yield reveal that cob yield was significantly highest under minimum tillage followed by ridges planting but all the three planting methods were significantly at par. This is due to the no difference in plant height, dry matter accumulation and leaf area index in any of the planting methods (Table 4).

Sub soiling done at various spacing was significantly better than where no sub soiling is done (Table 4). Sub soiling break up high density soil layer, improves infiltration and increases crop production. Highest biological yield was recorded under minimum tillage flat planting followed by conventional tillage ridge planting and the minimum tillage flat planting was significantly better than conventional tillage flat planting and conventional tillage ridge planting (Table 4). The biological yield is increased due to the cumulative effect of thousand grain weight, grain weight per cob, stover yield and cob 
yield which were non-significant but more in the minimum tillage flat planting. In sub soiling the all treatments of sub soiling was statistically at par and significantly better than where no sub soiling is done (Table 4).

The data revealed that different methods of planting did not affect 1000 grain weight. Minimum tillage flat planting showed the highest 1000 grain weight but all the planting methods were statistically at par (Table 4).

Sub soiling done at different spacing shows the significantly better results than where is no sub soiling is done (Table 4).

Highest grain yield (45.7 q/ha) was recorded under minimum tillage flat planting while $45.2 \mathrm{q} / \mathrm{hq}$ grain yield was recorded in conventional tillage ridge planting and all the three planting method treatments were statistically at par (Table 4). Grain yield was effected by the sub soiling treatments as where there is sub soiling is done is significantly better than where no sub soiling is done (Table 4).

Increase in plant height of the crop as well as dry matter accumulation in sub soiling treatment is the reason for increase in the grain yield.

Soil physical properties like bulk density and penetration resistance were also decreased which leads to better growth of the plants and increases the crop yield.

Sub soiling reduces the compaction and did not restrict the crop roots which were attributable to greater utilization of sub-soil moisture and increases the yield of the crop.

Table.1 Effect of planting methods and sub soiling on periodic plant height of kharif maize

\begin{tabular}{|c|c|c|c|}
\hline \multirow[b]{2}{*}{ Treatments } & \multicolumn{3}{|c|}{ Plant height $(\mathrm{cm})$} \\
\hline & 30 DAS & $\begin{array}{c}60 \\
\text { DAS }\end{array}$ & $\begin{array}{c}\text { At } \\
\text { harves } \\
\mathbf{t}\end{array}$ \\
\hline \multicolumn{4}{|l|}{ Planting methods } \\
\hline $\begin{array}{l}\text { Minimum tillage flat } \\
\text { planting }\end{array}$ & 60.1 & 206.3 & 221.7 \\
\hline $\begin{array}{l}\text { Conventional tillage flat } \\
\text { planting }\end{array}$ & 60.2 & 203.9 & 220.2 \\
\hline $\begin{array}{l}\text { Conventional tillage } \\
\text { ridge planting }\end{array}$ & 60.9 & 204.9 & 220.8 \\
\hline $\operatorname{LSD}(\mathrm{p}=0.05)$ & NS & NS & NS \\
\hline \multicolumn{4}{|l|}{ Subsoiling } \\
\hline No subsoiling & 58.4 & 199.6 & 215.8 \\
\hline Subsoiling at $1 \mathrm{~m}$ & 59.8 & 204.7 & 220.9 \\
\hline Subsoiling at $1 \times 1 \mathrm{~m}$ & 60.6 & 207.2 & 222.6 \\
\hline \multicolumn{4}{|c|}{ Subsoiling at $1.5 \mathrm{~m} 60.6205 .1221 .7$} \\
\hline Subsoiling at $1.5 \times 1.5 \mathrm{~m}$ & 62.6 & 208.7 & 223.4 \\
\hline $\operatorname{LSD}(\mathrm{p}=0.05)$ & NS & 4.43 & 3.38 \\
\hline $\begin{array}{l}\text { LSD for interactions } \\
(p=0.05)\end{array}$ & NS & NS & NS \\
\hline
\end{tabular}


Table.2 Effect of planting methods and sub soiling on periodic leaf area index of kharif maize

\begin{tabular}{|c|c|c|c|}
\hline \multirow{2}{*}{ Treatments } & \multicolumn{3}{|c|}{ Leaf Area Index (LAI) } \\
\hline & 30 DAS & 60 DAS & At harvest \\
\hline Planting methods & & & \\
\hline $\begin{array}{l}\text { Minimum tillage flat } \\
\text { planting }\end{array}$ & 0.5 & 3.6 & 3.1 \\
\hline $\begin{array}{l}\text { Conventional tillage flat } \\
\text { planting }\end{array}$ & 0.4 & 3.6 & 3.0 \\
\hline $\begin{array}{l}\text { Conventional tillage ridge } \\
\text { planting }\end{array}$ & 0.4 & 3.5 & 3.1 \\
\hline $\operatorname{LSD}(p=0.05)$ & NS & NS & NS \\
\hline Subsoiling & & & \\
\hline No subsoiling & 0.4 & 3.2 & 2.9 \\
\hline Subsoiling at $1 \mathrm{~m}$ & 0.4 & 3.6 & 3.2 \\
\hline Subsoiling at $1 \times 1 \mathrm{~m}$ & 0.5 & 3.7 & 3.3 \\
\hline Subsoiling at $1.5 \mathrm{~m}$ & 0.4 & 3.6 & 3.2 \\
\hline Subsoiling at $1.5 \times 1.5 \mathrm{~m}$ & 0.5 & 3.7 & 3.4 \\
\hline $\operatorname{LSD}(p=0.05)$ & NS & 0.2 & 0.3 \\
\hline $\begin{array}{l}\text { LSD for interactions } \\
(\mathrm{p}=0.05)\end{array}$ & NS & NS & NS \\
\hline
\end{tabular}

Table.3 Effect of planting methods and sub soiling on periodic Dry matter accumulation of kharif maize

\begin{tabular}{|c|c|c|c|}
\hline \multirow{2}{*}{ Treatments } & \multicolumn{3}{|c|}{ Dry matter accumulation $\left(\right.$ g plant $\left.^{-1}\right)$} \\
\hline & 30 DAS & 60 DAS & At harvest \\
\hline \multicolumn{4}{|l|}{ Planting methods } \\
\hline $\begin{array}{l}\text { Minimum tillage flat } \\
\text { planting }\end{array}$ & 35.9 & 153.7 & 227.0 \\
\hline $\begin{array}{l}\text { Conventional tillage flat } \\
\text { planting }\end{array}$ & 35.2 & 152.8 & 226.1 \\
\hline $\begin{array}{l}\text { Conventional tillage ridge } \\
\text { planting }\end{array}$ & 35.5 & 153.0 & 226.4 \\
\hline $\operatorname{LSD}(p=0.05)$ & NS & NS & NS \\
\hline \multicolumn{4}{|l|}{ Subsoiling } \\
\hline No subsoiling & 32.4 & 147.8 & 219.6 \\
\hline Subsoiling at $1 \mathrm{~m}$ & 33.8 & 153.6 & 226.5 \\
\hline Subsoiling at $1 \times 1 \mathrm{~m}$ & 38.3 & 154.7 & 228.9 \\
\hline Subsoiling at $1.5 \mathrm{~m}$ & 34.3 & 154.0 & 228.0 \\
\hline Subsoiling at $1.5 \times 1.5 \mathrm{~m}$ & 39.0 & 155.6 & 229.3 \\
\hline $\operatorname{LSD}(p=0.05)$ & NS & 2.90 & 4.29 \\
\hline $\begin{array}{l}\mathrm{LSD} \text { for interactions } \\
(\mathrm{p}=0.05)\end{array}$ & NS & NS & NS \\
\hline
\end{tabular}


Table.4 Effect of planting methods and sub soiling on cob length, 1000 grain weight, grain yield, cob yield and biological yield

\begin{tabular}{lccccc}
\hline \multicolumn{1}{c}{ Treatments } & $\begin{array}{c}\text { Cob } \\
\text { length } \\
\text { (cm) }\end{array}$ & $\begin{array}{c}\text { 1000 grain } \\
\text { weight }(\mathbf{g})\end{array}$ & $\begin{array}{c}\text { Grain yield } \\
(\mathbf{q} / \mathbf{h a})\end{array}$ & $\begin{array}{c}\text { Cob } \\
\text { yield } \\
(\mathbf{q} / \mathbf{h a})\end{array}$ & $\begin{array}{c}\text { Biological } \\
\text { yield } \\
(\mathbf{q} / \mathbf{h a})\end{array}$ \\
\hline $\begin{array}{l}\text { Planting methods } \\
\text { Minimum tillage-flat } \\
\text { planting }\end{array}$ & 20.9 & 290.5 & 45.7 & 70.5 & 176.5 \\
$\begin{array}{l}\text { Conventional tillage-flat } \\
\text { planting }\end{array}$ & 20.7 & 289.7 & 45.0 & 70.1 & 175.6 \\
$\begin{array}{l}\text { Conventional tillage ridge } \\
\text { planting }\end{array}$ & 20.8 & 290.0 & 45.2 & 70.2 & 175.9 \\
$\begin{array}{l}\text { LSD (p=0.05) } \\
\text { Subsoiling }\end{array}$ & $\mathrm{NS}$ & $\mathrm{NS}$ & $\mathrm{NS}$ & $\mathrm{NS}$ & 0.45 \\
$\begin{array}{l}\text { No subsoiling } \\
\text { Subsoiling at }\end{array}$ & 20.4 & 287.4 & 42.6 & 68.4 & 171.7 \\
$\begin{array}{l}\text { 1m } \\
\begin{array}{l}\text { Subsoiling at } \\
\text { 1x1m }\end{array}\end{array}$ & 20.5 & 290.0 & 45.7 & 70.8 & 176.9 \\
$\begin{array}{l}\text { Subsoiling at } \\
1.5 \mathrm{~m}\end{array}$ & 20.9 & 291.3 & 46.1 & 70.7 & 177.0 \\
$\begin{array}{l}\text { Subsoiling at } \\
1.5 x 1.5 \text { m }\end{array}$ & 20.6 & 290.3 & 45.8 & 70.7 & 177.0 \\
$\begin{array}{l}\text { LSD (p=0.05) } \\
\text { LSD for } \\
\text { interactions (p=0.05) }\end{array}$ & 21.0 & 291.4 & 46.4 & 70.8 & 177.5 \\
\hline & $\mathrm{NS}$ & 1.55 & 1.51 & 0.76 & 1.21 \\
\hline
\end{tabular}

Table.5 Effect of planting methods and subsoiling on bulk density of soil

\begin{tabular}{|c|c|c|c|}
\hline \multirow{2}{*}{ Treatments } & \multicolumn{3}{|l|}{ Soil depth } \\
\hline & $0-15 \mathrm{~cm}$ & $15-30 \mathrm{~cm}$ & $30-45 \mathrm{~cm}$ \\
\hline \multicolumn{4}{|l|}{ Planting methods } \\
\hline $\begin{array}{l}\text { Minimum tillage flat } \\
\text { planting }\end{array}$ & 1.44 & 1.45 & 1.47 \\
\hline $\begin{array}{l}\text { Conventional tillage flat } \\
\text { planting }\end{array}$ & 1.43 & 1.43 & 1.45 \\
\hline $\begin{array}{l}\text { Conventional tillage ridge } \\
\text { planting }\end{array}$ & 1.44 & 1.44 & 1.46 \\
\hline $\operatorname{LSD}(p=0.05)$ & NS & NS & NS \\
\hline \multicolumn{4}{|l|}{ Subsoiling } \\
\hline No subsoiling & 1.46 & 1.50 & 1.52 \\
\hline Subsoiling at $1 \mathrm{~m}$ & 1.44 & 1.42 & 1.45 \\
\hline Subsoiling at $1 \times 1 \mathrm{~m}$ & 1.40 & 1.41 & 1.43 \\
\hline Subsoiling at $1.5 \mathrm{~m}$ & 1.44 & 1.44 & 1.46 \\
\hline Subsoiling at $1.5 \times 1.5 \mathrm{~m}$ & 1.43 & 1.42 & 1.44 \\
\hline $\operatorname{LSD}(\mathrm{p}=0.05)$ & NS & 0.04 & 0.04 \\
\hline $\begin{array}{l}\text { LSD for interactions } \\
(p=0.05)\end{array}$ & NS & NS & NS \\
\hline
\end{tabular}


Table.6 Effect of planting methods on infiltration rate $\left(\mathrm{cm} \mathrm{hr}^{-1}\right)$

\begin{tabular}{|l|c|c|c|c|c|c|c|c|c|c|c|c|}
\hline $\begin{array}{l}\text { Planting } \\
\text { methods }\end{array}$ & \multicolumn{10}{|c|}{ Time interval (min) } \\
\hline & 1 & 3 & 5 & 10 & 15 & 25 & 40 & 60 & 80 & 100 & 140 & 180 \\
\hline $\begin{array}{l}\text { Minimum } \\
\text { tillage flat } \\
\text { planting }\end{array}$ & 69.6 & 30 & 21.6 & 12.48 & 8.88 & 5.28 & 3.78 & 2.64 & 2.04 & 2.24 & 1.28 & 1.21 \\
\hline $\begin{array}{l}\text { Conventional } \\
\text { tillage flat } \\
\text { planting }\end{array}$ & 75.6 & 30 & 19.8 & 12.24 & 8.4 & 5.08 & 3.76 & 2.64 & 2.16 & 1.92 & 1.23 & 1.23 \\
\hline $\begin{array}{l}\text { Conventional } \\
\text { tillage ridge } \\
\text { planting }\end{array}$ & 68.4 & 30 & 19.8 & 12.24 & 8.16 & 5.16 & 3.76 & 2.58 & 2.22 & 2.16 & 1.26 & 1.17 \\
\hline
\end{tabular}

Table.7 Effect of subsoiling on infiltration rate $\left(\mathrm{cm} \mathrm{hr}^{-1}\right)$

\begin{tabular}{|l|l|l|l|l|l|l|l|l|l|l|l|l|}
\hline Subsoiling & \multicolumn{10}{|c|}{ Time interval (min) } \\
\hline & $\mathbf{1}$ & $\mathbf{3}$ & $\mathbf{5}$ & $\mathbf{1 0}$ & $\mathbf{1 5}$ & $\mathbf{2 5}$ & $\mathbf{4 0}$ & $\mathbf{6 0}$ & $\mathbf{8 0}$ & $\mathbf{1 0 0}$ & $\mathbf{1 4 0}$ & $\mathbf{1 8 0}$ \\
\hline No subsoiling (So) & 62 & 24 & 16 & 8.8 & 6 & 4.6 & 2.93 & 2.4 & 2.1 & 1.7 & 0.95 & 0.9 \\
\hline $\begin{array}{l}\text { Subsoiling at 1 m } \\
\text { (S1) }\end{array}$ & 70 & 32 & 23 & 14.4 & 9.2 & 5.4 & 4 & 2.4 & 2.1 & 1.9 & 1.3 & 1.25 \\
\hline $\begin{array}{l}\text { Subsoiling at 1x1 } \\
\text { m (S2) }\end{array}$ & 80 & 32 & 21 & 13.2 & 8.4 & 5.4 & 3.86 & 3.1 & 2.3 & 2.1 & 1.45 & 1.35 \\
\hline $\begin{array}{l}\text { Subsoiling at 1.5 } \\
\text { m (S3) }\end{array}$ & 62 & 29 & 21 & 12 & 9.2 & 5.8 & 4.13 & 2.6 & 2.1 & 2.1 & 1.2 & 1.1 \\
\hline $\begin{array}{l}\text { Subsoiling at } \\
1.5 x 1.5 \mathrm{~m} \text { (S4) }\end{array}$ & 82 & 33 & 21 & 13.2 & 9.6 & 5.2 & 3.73 & 2.6 & 2.1 & 1.8 & 1.3 & 1.25 \\
\hline
\end{tabular}

Table.8 Effect of planting methods and subsoiling on soil penetration resistance $(\mathrm{kPa})$

\begin{tabular}{|c|c|c|c|}
\hline \multirow{2}{*}{ Treatments } & \multicolumn{3}{|l|}{ Soil depth } \\
\hline & $10 \mathrm{~cm}$ & $20 \mathrm{~cm}$ & $30 \mathrm{~cm}$ \\
\hline \multicolumn{4}{|l|}{ Planting methods } \\
\hline $\begin{array}{l}\text { Minimum tillage flat } \\
\text { planting }\end{array}$ & 467.5 & 1560.2 & 2505.7 \\
\hline $\begin{array}{l}\text { Conventional tillage flat } \\
\text { planting }\end{array}$ & 446.7 & 1513.5 & 2445.5 \\
\hline $\begin{array}{l}\text { Conventional tillage ridge } \\
\text { planting }\end{array}$ & 456.1 & 1541.0 & 2483.6 \\
\hline $\operatorname{LSD}(\mathrm{p}=0.05)$ & 13.34 & NS & NS \\
\hline \multicolumn{4}{|l|}{ Subsoiling } \\
\hline No subsoiling & 567.1 & 1619.6 & 2546.0 \\
\hline Subsoiling at $1 \mathrm{~m}$ & 436.1 & 1535.0 & 2478.3 \\
\hline Subsoiling at $1 \times 1 \mathrm{~m}$ & 395.6 & 1463.5 & 2385.0 \\
\hline Subsoiling at $1.5 \mathrm{~m}$ & 461.6 & 1567.8 & 2517.3 \\
\hline Subsoiling at $1.5 \times 1.5 \mathrm{~m}$ & 423.1 & 1505.1 & 2464.6 \\
\hline $\operatorname{LSD}(\mathrm{p}=0.05)$ & 16.46 & 21.43 & 16.39 \\
\hline $\begin{array}{l}\text { LSD for interactions } \\
(p=0.05)\end{array}$ & NS & NS & NS \\
\hline
\end{tabular}




\section{Effect on soil properties}

Data on bulk density $\left(\mathrm{g} \mathrm{cm}^{-3}\right)$ revealed that all the planting method treatments were statistically at par in all the three layers i.e there is no significant difference between the minimum tillage flat planting, conventional tillage flat planting and the conventional tillage ridge planting at $0-15 \mathrm{~cm}, 15-30 \mathrm{~cm}$ and $30-45 \mathrm{~cm}$ (Table 5). Bulk density differ significantly in the sub soiling treatments at $15-30 \mathrm{~cm}$ and $30-45 \mathrm{~cm}$ as the all sub soiling treatment shows less bulk density than no sub soiling treatment (Table 5). All the interactions did not show any significant difference between the any of the treatment (Table 5). Infiltration rate $\left(\mathrm{cm} \mathrm{hr}^{-1}\right)$ was recorded under different planting method treatments. At initial stage conventional tillage flat planting shows higher infiltration rate than minimum tillage flat planting and conventional tillage ridge planting (Table 6). After that minimum tillage flat planting shows more infiltration rate at different time intervals $(5,10,15,25,40,100$ and 140 minutes) than conventional tillage flat planting and conventional tillage ridge planting (Table 6). The higher IR in the plots under minimum tillage was probably due to minimum disturbance that maintained the continuity of water conducting pores. The crop residues left on the soil surface limit evaporation, soil sealing and crusting and thereby increase soil infiltration. Infiltration rate was also effected by the sub soiling treatments. All the sub soiling treatments at various intervals show more infiltration rate than where no sub soiling is done. Sub soiling done at $1 \times 1 \mathrm{~m}$ and $1 \mathrm{~m}$ shows more infiltration at initial time interval but after that sub soiling done at $1.5 \times 1.5 \mathrm{~m}$ shows nearly similar infiltration rate with other sub soiling treatments. Only no sub soiling treatment shows less infiltration rate (Table 7). It may be due to more compaction in soil as well as un-equal distribution of pores in the soil. The restrictive compact layer at various depth may not allow water to infiltrate regularly at different intervals.

Data on penetration resistance revealed that there is significant difference at $10 \mathrm{~cm}$ depth between the planting methods as well as sub soiling treatments (Table 8). Conventional tillage flat planting showed less penetration resistance than minimum tillage flat planting and conventional tillage ridge planting but statistically at par with conventional tillage ridge planting. Minimum tillage flat planting shows highest penetration resistance. This may be due to the residues retained on surface as well as soil compaction under the minimum tillage. In sub soiling treatments sub soiling done at $1 \times 1 \mathrm{~m}$ showed least penetration resistance and differ significantly with all other sub soiling treatments (Table 8).

No sub soiling treatment showed highest penetration resistance. At $20 \mathrm{~cm}$ depth there is no significant difference between the planting methods. Sub soiling treatments differ significantly as sub soiling done at $1 \times 1 \mathrm{~m}$ showed least penetration resistance while no sub soiling treatment showed highest penetration resistance. At $30 \mathrm{~cm}$ depth there is no significant difference between planting methods. Sub soiling done at $1 \times 1 \mathrm{~m}$ showed least penetration resistance while sub soiling done at $1 \mathrm{~m}$ and at $1.5 \times 1.5 \mathrm{~m}$ are statistically at par with each other but significantly differ with other treatments (Table 8). All the interactions did not show any significant difference between the any of the treatment (Table 8). Less resistance was found due to sub soiling because of reduced soil compaction as bulk density is decreased.

In conclusion, the research findings revealed that sub soiling improves the physical properties of soil like bulk density, penetration resistance and infiltration rate. All the planting methods i.e. (minimum tillage- 
flat planting, conventional tillage-flat planting and conventional tillage-ridge planting) were equally effective in relation to productivity of the crop. Sub soiling done at various distances also showed the statistically par results but significantly better than no sub soiling in relation to crop yield. However, less cost was involved in the minimum tillage flat planting and sub soiling done at $1.5 \mathrm{~m}$ distance.

\section{References}

Bennie A T P and Botha F J P (1986) Effect of deep tillage and controlled traffic on root growth, water-use efficiency and yield of irrigated maize and wheat. Soil Tillage Res 7:85-95.

Hammel J E (1994) Effect of high-axle load traffic on subsoil physical properties and crop yields in the Pacific Northwest USA. Soil Tillage Res 29:159-203.

Hamza M A and Anderson W K (2005). Soil compaction in cropping systems a review of the nature, causes and possible solutions. Soil Tillage Res82:121-45.

Lal R A, Mohboubi and Fausey N R (1994) Long-term tillage and rotation effects on properties of central Ohio soils. Soil
SciSoc American J58: 517-22.

Raimbault B A, Vyn T J (1991) Crop rotation and tillage effects on corn growth and soil structural stability. Agron $J$ 83: 979-85.

Ram H, Yadwinder S, Saini K S, Kler D S, Timsinas J and Humphreys E J (2010) Agronomic and economic evaluation of permanent raised beds, no tillage and straw mulching for an irrigated maizewheat system in northwest India. ExplAgric48:21-38.

Ramesh, Rana S S, Negi S C, Kumar S and Subehia S K (2014) Effects of resource conserving and planting techniques on productivity of maize -wheat cropping system. Indian J Agron59:34-40.

Unger P W (1991) Organic matter nutrient and $\mathrm{pH}$ distribution in no and conventional tillage in semiarid soils. Agron J83: 186-89.

Varsa E C, Chong S K, Abolaji J O, Farquhar D A and Olsen F J (1997) Effect of deep-tillage on soil physical characteristics and corn (Zea mays L.) root growth and production. Soil Tillage Res 43:219-28

\section{How to cite this article:}

Gurbir Singh, J.S. Kang and Harmeet Singh. 2017. Productivity of Kharif Maize (Zea mays L.) as Influenced by Sub Soiling and Planting Methods. Int.J.Curr.Microbiol.App.Sci. 6(7): 513521. doi: https://doi.org/10.20546/ijcmas.2017.607.062 